\title{
EFEK HEPAPROTEKTIF GULA AREN TERHADAP KARBON TETRAKLORIDA PADA TIKUS
}

\author{
Elly Juliana Suoth ${ }^{1 *}$, Rina Herowati ${ }^{2}$ dan Gunawan Pamudji ${ }^{2}$ \\ ${ }^{1}$ Program Studi Farmasi, Fakultas Matematika dan Ilmu Pengetahuan Alam Universitas Sam Ratulangi Manado \\ Jl. Kampus Unsrat, Kleak, Manado 95115 Sulawesi Utara \\ ${ }^{2}$ Fakultas Farmasi, Universitas Setia Budi, Surakarta
}

\begin{abstract}
ABSTRAK
Studi ini meneliti efek gula aren, senyawa bioaktif yang diisolasi dari gula aren, terhadap kerusakan hati akibat karbon tetraklorida $\left(\mathrm{CCl}_{4}\right)$. Tikus diperlakukan secara intraperitoneal dengan $0,5 \mathrm{ml} / \mathrm{kg} \mathrm{CCl} / 4$ dan kelompok hewan yang berbeda menerima $25,50,100$, dan $200 \mathrm{mg} / \mathrm{kg}$ sudar palem. Pada 24 jam setelah perawatan $\mathrm{CCl}_{4}$, kadar aminotransferase serum dan peroksidasi lipid meningkat secara signifikan, sedangkan kadar glutathione hati menurun. Perubahan ini dilemahkan oleh gula aren. Studi histologis menunjukkan bahwa gula aren menghambat peradangan portal, nekrosis sentrizonal, dan hiperplasia sel Kupffer, yang merupakan tiga karakteristik paling umum dari kerusakan hati yang diinduksi $\mathrm{CCl}_{4}$. Tingkat serum dan mRNA ekspresi tumor necrosis factor-a secara nyata meningkat dengan pengobatan $\mathrm{CCl}_{4}$ tetapi ditekan oleh gula aren. Level mRNA dan ekspresi protein diinduksi nitric oxide synthase dan heme oksigenase-1 meningkat secara signifikan pada 24 jam setelah perawatan $\mathrm{CCl}_{4}$. Gula aren melemahkan peningkatan protein dan ekspresi gen diinduksi nitric oxide synthase tetapi menambah peningkatan heme oxygenase-1. Temuan ini menunjukkan bahwa gula aren melindungi hepatosit dari kerusakan oksidatif yang disebabkan oleh $\mathrm{CCl}_{4}$, dan perlindungan ini kemungkinan disebabkan oleh induksi ekspresi HO-1 dan penghambatan mediator proinflamasi.
\end{abstract}

Kata kunci: Gula merah, karbon tetraklorida, stress oksidatif

\section{ABSTRACT}

This study examined the effects of palm sugar, a bioactive compounds isolated from palm sugar, on carbon tetrachloride $\left(\mathrm{CCl}_{4}\right)$-induced liver injury. Mice were treated intraperitoneally with $0.5 \mathrm{ml} / \mathrm{kg} \mathrm{CCl} 4$ and different groups of animals received $25,50,100$, and $200 \mathrm{mg} / \mathrm{kg}$ palm sudar. At $24 \mathrm{~h}$ after the CCl 4 treatment, the level of serum aminotransferases and lipid peroxidation was significantly elevated, whereas the hepatic glutathione content was decreased. These changes were attenuated by palm sugar. The histological studies showed that palm sugar inhibited the portal inflammation, centrizonal necrosis, and Kupffer cell hyperplasia, which are the three most common characteristics of $\mathrm{CCl}_{4}$-induced liver damage. The serum level and mRNA expression of tumor necrosis factor- $\alpha$ were markedly increased by the $\mathrm{CCl}_{4}$ treatment but suppressed by palm sugar. The mRNA and protein expression levels of inducible nitric oxide synthase and heme oxygenase-1 increased significantly at $24 \mathrm{~h}$ after the $\mathrm{CCl}_{4}$ treatment. Palm sugar attenuated the increase in the protein and gene expression of inducible nitric oxide synthase but augmented the increase in those of heme oxygenase-1. These findings suggest that palm sugar protects hepatocytes from the oxidative damage caused by $\mathrm{CCl}_{4}$, and this protection is likely due to the induction of HO-1 expression and the inhibition of the proinflammatory mediators.

Keywords: Palm sugar, carbon tetrachloride, oxidative stress

\section{PENDAHULUAN}

Gula aren merupakan salah satu komoditi utama di daerah Sulawesi Utara khususnya Minahasa (Minahasa Selatan, Minahasa tenggara, Tomohon) yang sampai saat ini pemasarannya tidak hanya secara lokal ataupun nasional namun telah mencapai pasar internasional. Gula aren dihasilkan dari nira pohon aren (Arenga pinnata) yang dipanaskan kemudian dibentuk menjadi gula aren serbuk dan juga ada yang dibentuk dengan menggunakan cetakan batok kelapa (padatan gula aren). Gula aren banyak digunakan sebagai pemanis pada makanan dan minuman maupun digunakan sebagai obat tradisional untuk mengobati berbagai macam penyakit yang dikombinasikan dengan bahan tumbuhan alami lainnya. Salah satunya adalah gula aren yang biasa digunakan oleh Masyarakat Sulawesi Utara sebagai obat untuk mengatasi penyakit kuning atau liver. Selain digunakan secara empiris oleh masyarakat berbagai penelitian pun sudah banyak

\footnotetext{
Korespondensi:

Telepon: +62 852-4030-8901

Email: ellysuoth@gmail.com

DOI: https://doi.org/10.35799/cp.12.1.2019.27303
} 
dilakukan untuk mengetahui khasiat dari gula aren tersebut seperti penelitian yang dilakukan oleh Adriani dkk., (2014) yang menguji tentang pengaruh dari pemberian gula aren dan juice buah noni terhadap kadar SGOT dan SGPT pada hewan uji.

Penelitian yang ada telah membuktikan bahwa gula aren memiliki aktivitas sebagai antioksidan dan stabil pada pemanasan dengan metode FRAP (Pelealu dkk., 2011) serta penelitian dari Amin dkk. (2010) yang melaporkan aktivitas antioksidan gula aren dengan metode DPPH selain itu Choong dkk., (2016) melaporkan berdasarkan hasil penelitian perbandingan aktivitas antioksidan antara gula aren dengan gula putih dimana gula aren memiliki aktivitas antioksidan sebesar 28,88 $\%$ sedangkan gula putih hanya memiliki aktivitas antioksidan sebesar $0,16 \%$. Aktivitas antioksidan dari gula aren kemungkinan disebabkan oleh senyawa melanoidin yang terbentuk selama pemanasan pada proses pembuatan gula tersebut. Berdasarkan hasil laboratorium menunjukkan bahwa pada gula aren selain mengandung karbohidrat juga mengandung asam-asam amino protein yang dapat bereaksi membentuk reaksi Mailard pada proses pemanasan. Selain itu berdasarkan hasil penelitian pendahuluan yang dilakukan diperoleh bahwa pemberian gula aren pada hewan uji tikus putih dengan tiga variasi dosis yaitu $125 \mathrm{mg} / \mathrm{kg} \mathrm{BB}, 250 \mathrm{mg} / \mathrm{kg} \mathrm{BB}$ dan 500 $\mathrm{mg} / \mathrm{kg}$ BB selama dua minggu dapat menurunkan nilai AST dan ALT dari hewan uji yang di induksi dengan $\mathrm{CCl}_{4}$. Hasil pendahuluan yang diperoleh pada kontrol negatif kadar ALT rata-ratanya yaitu 38,26 U/I sedangkan pada gula aren dosis 125 $\mathrm{mg} / \mathrm{kg}$ BB kadar ALT rata-ratanya yaitu 27, $58 \mathrm{U} / \mathrm{I}$ dan 23,11 U/I serta 20,78 U/I pada dosis 250 dan $500 \mathrm{mg} / \mathrm{kg} \mathrm{BB}$, yang berdasarkan hasil analisis dengan statistika ketiga dosis gula aren tersebut berbeda dengan kontrol negatif yang ditunjukkan dengan nilai $\mathrm{P}=0,000<0,05$. Hal yang sama juga berlaku pada kadar AST.

\section{BAHAN DAN METODE}

\section{Bahan dan alat}

Bahan yang digunakan dalam penelitian ini adalah gula aren serbuk yang diperoleh dari pabrik gula aren Yayasan Masarang di Tomohon, Sulawesi Utara. Bahan untuk induksi yang digunakan adalah $\mathrm{CCl}_{4} \quad 1,5 \mathrm{ml} / \mathrm{kg} \mathrm{BB}$ dengan konsentrasi $50 \%$ dalam larutan minyak kelapa serta bahan uji untuk ALT dan AST. Alat yang digunakan dalam penelitian ini adalah timbangan, mikropipet, inkubator sentrifuge spektrofotometer, inkubator serta alat-alat gelas lainnya yang lazim digunakan dalam laboratorium.

\section{Perlakuan terhadap hewan uji}

Tikus dipuasakan kemudian ditimbang. Pada hari pertama dilakukan pengambilan darah untuk mengukur kadar ALT dan AST dari tikus sebelum dilakukan perlakuan, kemudian pada hari itu juga diberikan gula aren sesuai dengan dosis $200 \mathrm{mg} / \mathrm{kg}$ BB dan $400 \mathrm{mg} / \mathrm{kg}$ BB selama 14 hari dan pada hari ke-15 diberikan larutan $\mathrm{CCl}_{4}$ sebanyak $1,5 \mathrm{ml} / \mathrm{kg}$ BB. 24 jam setelah pemberian $\mathrm{CCl}_{4}$ diambil kembali darah tikus untuk mengukur kadar ALT dan AST sesudah perlakuan. Pengukuran kadar ALT dan AST pada darah tikus dilakukan sebanyak 3 kali pengukuran yaitu pada 0 hari, hari ke-7 dan hari ke-16 setelah induksi $\mathrm{CCl}_{4}$

\section{Pengukuran kadar AST}

Penetapan aktivitas AST ditetapkan berdasarkan reaksi enzimatik menggunakan reagen kit Dyasis ${ }^{\circledR}$ AST (R1) TRIS pH 7,65 sebanyak $110 \mathrm{mmol} / \mathrm{L}$, L-aspartate $320 \mathrm{mmol} / \mathrm{L}$, $\mathrm{MDH}$ (malate dehidrogenase) $\geq 800 \mathrm{U} / \mathrm{L}$ dan $\mathrm{LDH}$ (laktate dehidrogenase) $\geq 1200 \mathrm{U} / \mathrm{L}$; reagen AST (R2) 2-oksoglutarate $65 \mathrm{mmol} / \mathrm{L}$ dan NADH 1 $\mathrm{mmol} / \mathrm{L}$. Larutan sampel berisi campuran R1 dan R2 dengan perbandingan $4: 1$. Sebanyak $600 \mu 1$ reagen kit AST direaksikan dengan $60 \mu \mathrm{l}$ sampel, kemudian dihomogenkan dan diinkubasi pada suhu kamar selama 1 menit selanjutnya sampel dibaca absorbansinya menggunakan spektrofotometer pada panjang gelombang $340 \mathrm{~nm}$

\section{Pengukuran kadar ALT}

Penetapan aktivitas ALT ditetapkan berdasarkan reaksi enzimatik menggunakan reagen kit Dyasis ${ }^{\circledR}$ ALT (RI) TRIS pH 7,15 sebanyak $140 \mathrm{mmol} / \mathrm{L}$, L-alanine $700 \mathrm{mmol} / \mathrm{L}$ dan LDH (laktate dehidrogenase) $\geq 2300 \mathrm{U} / \mathrm{L}$; reagen ALT (RII) 2-oksoglutarate $85 \mathrm{mmol} / \mathrm{L}$ dan NADH $1 \mathrm{mmol} / \mathrm{L}$. Larutan sampel berisi campuran reagen I dan reagen 2 dengan perbandingan $4: 1$. Sebanyak $600 \mu$ reagen kit ALT direaksikan dengan $60 \mu \mathrm{l}$ sampel, di vortex dan diinkubasi pada suhu kamar selama 1 menit selanjutnya sampel dibaca absorbansinya menggunakan spektrofotometer pada panjang gelombang 340 $\mathrm{nm}$.

\section{Uji histopatologi}

Hewan uji dikorbankan dengan cara anestesi, diambil seluruh bagian dari organ hati 
kemudian dibuat preparat histopatologi. Jaringan akan mengalami autolysis ketika terlepas dari tubuh sehngga untuk mengamati jaringan dengan struktur yang mendekati struktur ketika masih hidup maka perlu dilakukan fiksasi kemudian dilakukan pewarnaan dan pengamatan jaringan dengan mikroskop.

\section{HASIL DAN PEMBAHASAN}

Hasil pengukuran berat badan tikus

Pengukuran berat badan tikus dilakukan secara bertahap yang bertujuan untuk melihat ada tidaknya perubahan yang dipengaruhi oleh karena pemberian perlakuan baik itu dengan gula aren serbuk maupun dengan pemberian kontrol positif sebelum dan sesudah diinduksi dengan $\mathrm{CCl}_{4}$.

Tabel 1. Berat badan tikus dan perubahannya

\begin{tabular}{cccccc}
\hline Kelompok & \multicolumn{5}{c}{ Berat Badan Tikus (gram) } \\
& 0 hari & Hari ke-7 & Hari ke-14 & Hari ke-16 & \\
\hline I & $195,6 \pm 5,1$ & $201,8 \pm 6,0$ & $206,4 \pm 4,2$ & $207,6 \pm 4,9$ & $12^{*}$ \\
II & $199,0 \pm 6,3$ & $206,8 \pm 6,9$ & $213,4 \pm 5,6$ & $211,2 \pm 5,5$ & $12.2^{*}$ \\
III & $197,8 \pm 3,9$ & $204,6 \pm 3,5$ & $211,6 \pm 4,3$ & $212,2 \pm 4,0$ & 14.4 \\
IV & $199,2 \pm 3,0$ & $205,6 \pm 3,3$ & $211,4 \pm 3,3$ & $210,0 \pm 2,7$ & $10.8^{*}$ \\
V & $193,6 \pm 2,6$ & $200,2 \pm 1,9$ & $205,0 \pm 2,9$ & $206,0 \pm 3,3$ & $12.4^{*}$ \\
\hline
\end{tabular}

Tanda * menunjukkan $\mathrm{P}<0,05$ dibandingkan dengan kontrol positif

Berat badan pada kelompok kontrol negatif berbeda signifikan dengan kelompok positif namun tidak berbeda signifikan dengan kelompok kontrol normal dan kelompok gula aren dosis 200 $\mathrm{mg} / \mathrm{kg}$ serta kelompok gula aren dosis $400 \mathrm{mg} / \mathrm{kg}$. Hal tersebut menunjukkan bahwa induksi $\mathrm{CCl}_{4}$ yang dilakukan hanya sekali dengan waktu 24 jam tidak mempengaruhi berat badan dari hewan uji.

\section{Hasil pengukuran kadar ALT dan AST pada darah tikus}

Pengukuran kadar ALT dan AST dilakukan sebanyak tiga kali yaitu pada awal sebelum diberikan perlakuan, hari ke 7 setelah diberikan perlakuan dan setelah diinduksi dengan $\mathrm{CCl}_{4}$ yaitu pada hari ke-16.

Tabel 2. Hasil pengukuran kadar ALT tikus

\begin{tabular}{cccll}
\hline \multirow{2}{*}{ Kelompok } & \multicolumn{4}{c}{ ALT } \\
\cline { 2 - 5 } & \multicolumn{1}{c}{0 Hari } & Hari ke-7 & \multicolumn{1}{c}{ Hari ke-16 } & Selisih \\
\hline I & $18,35 \pm 0,4$ & $19,42 \pm 0,4$ & $18,44 \pm 0,3$ & 0.10 \\
II & $18,35 \pm 0,4$ & $19,42 \pm 0,3$ & $37,18 \pm 2,1^{\text {a }}$ & 18.84 \\
III & $18,25 \pm 0,7$ & $20,29 \pm 0,4$ & $23,01 \pm 0,6^{\text {ab }}$ & 4.76 \\
IV & $17,96 \pm 0,3$ & $20,00 \pm 0,2$ & $31,84 \pm 0,5^{\text {abc }}$ & 13.89 \\
V & $18,35 \pm 0,4$ & $19,80 \pm 0,8$ & $26,11 \pm 0,7^{\text {abcd }}$ & 7.77 \\
\hline
\end{tabular}

Keterangan huruf: a: menunjukkan $\mathrm{p}<0,05$ dibandingkan dengan kontrol normal, b: menunjukkan $\mathrm{p}<0,05$ dibandingkan dengan kontrol negatif, c: menunjukkan $\mathrm{p}<0,05$ dibandingkan dengan kontrol positif, d: menunjukkan $\mathrm{p}<0,05$ dibandingkan dengan dosis gula aren $200 \mathrm{mg} / \mathrm{kgBB}$. Keterangan: I (kelompok normal, II (kelompok kontrol negatif), III (kelompok kontrol positif, Hepamax, IV (gula aren dosis $200 \mathrm{mg} / \mathrm{kg} \mathrm{BB}$ ) dan V (gula aren dosis $400 \mathrm{mg} / \mathrm{kg} \mathrm{BB}$ )

Hasil pengujian pada tabel 2 menunjukkan bahwa hasil uji kadar ALT pada 0 hari tidak terdapat perbedaan pada kelima kelompok. Hal yang serupa juga terjadi pada ALT hari ke-7 dimana berdasarkan hasil statistik antar kelompok tidak menunjukkan perbedaan yang signifikan. Tidak adanya perbedaan yang signifikan pada ALT 0 hari dan ALT hari ke-7 membuktikan bahwa pemberian kontrol positif juga pemberian gula aren dosis $200 \mathrm{mg} / \mathrm{kg}$ BB dan gula aren dosis $400 \mathrm{mg} / \mathrm{kg}$ BB tidak memberikan pengaruh terhadap kadar ALT hewan uji yang sehat.

Kadar ALT hari ke-16 merupakan kadar ALT setelah hewan uji diinduksi dengan $\mathrm{CCl}_{4}$ dan berdasarkan hasil uji statistika menunjukkan adanya perbedaan antar kelompok. Tabel 5 
menunjukkan bahwa kadar ALT hari ke-16 pada kelompok normal berbeda dengan kelompok kontrol negatif, juga dengan kelompok yang lainnya. Perbedaan kelompok normal dengan kelompok lainnya menujukkan bahwa induksi $\mathrm{CCl}_{4}$ yang dimaksudkan untuk merusak fungsi dari organ hati telah berhasil, dimana pada kelompok normal yang tidak diinduksi dengan $\mathrm{CCl}_{4}$ tidak terjadi peningkatan kadar ALT.

Kadar ALT hari ke-16 pada kelompok kontrol negatif berbeda dengan kelompok yang lainnya dimana pada kelompok kontrol negatif terjadi peningkatan kadar ALT yang terbesar. Hal ini menunjukkan bahwa pemberian larutan saline selama 14 hari tidak dapat melindungi kerusakan hati akibat induksi $\mathrm{CCl}_{4}$. Kelompok kontrol positif menunjukkan kadar ALT hari ke-16 yang berbeda dengan kelompok negatif dimana peningkatan kadar ALT hari ke-16 pada kelompok kontrol positif adalah yang terkecil. Hasil tersebut membuktikan bahwa pemberian Hepamax sebagai kontrol positif yang mengandung silimarin mampu melindungi hati dari kerusakan yang disebabkan oleh $\mathrm{CCl}_{4}$.

Kelompok gula aren dosis $200 \mathrm{mg} / \mathrm{kg} \mathrm{BB}$ dan dosis $400 \mathrm{mg} / \mathrm{kg}$ BB menunjukan kadar ALT pada hari ke-16 yang berbeda dengan kontrol positif juga berbeda dengan kontrol negatif. Hal ini menunjukkan bahwa kelompok gula aren juga mampu melindungi kerusakan yang terjadi di hati walaupun tidak sebesar perlidungan yang diberikan oleh hepamax sebagai kontrol positif.

Tabel 3. Hasil pengukuran kadar AST tikus

\begin{tabular}{cccll}
\hline Kelompok & \multicolumn{4}{c}{ AST } \\
\cline { 2 - 5 } & \multicolumn{1}{c}{0 Hari } & Hari ke-7 & \multicolumn{1}{c}{ Hari ke-16 } & Selisih \\
\hline I & $37,21 \pm 0,12$ & $39,03 \pm 0,4$ & $38,25 \pm 0,6$ & 1.04 \\
II & $37,38 \pm 0,7$ & $38,94 \pm 1,2$ & $77,09 \pm 3,6^{\text {a }}$ & 39.71 \\
III & $37,38 \pm 0,3$ & $39,23 \pm 0,6$ & $46,31 \pm 2,3^{\text {ab }}$ & 8.93 \\
IV & $37,77 \pm 0,6$ & $38,26 \pm 0,8$ & $58,72 \pm 1,5^{\text {abc }}$ & 20.95 \\
V & $37,67 \pm 0,5$ & $38,16 \pm 0,7$ & $49,90 \pm 0,6^{\text {abcd }}$ & 12.23 \\
\hline
\end{tabular}

Keterangan: a: menunjukkan $\mathrm{p}<0,05$ dibandingkan dengan kontrol normal, b: menunjukkan $\mathrm{p}<0,05$ dibandingkan dengan kontrol negatif, c: menunjukkan $\mathrm{p}<0,05$ dibandingkan dengan kontrol positif, d: menunjukkan $\mathrm{p}<0,05$ dibandingkan dengan dosis gula aren $200 \mathrm{mg} / \mathrm{kgBB}$

Kadar AST pada 0 hari dan hari ke-7 pada tabel 3 di atas tidak menunjukkan adanya perbedaan antar kelompok. Kadar AST pada hari ke-16 menunjukkan adanya perbedaan antar kelompok dan perbedaan-perbedaan tersebut terjadi sama seperti yang terlihat pada kadar ALT hari ke-16

Reaksi radikal bebas yang dihasilkan dari $\mathrm{CCl}_{4}$ pada penelitian ini dapat diredam oleh adanya pemberian Hepamax sebagai kontrol positif dan gula aren pada hewan uji. Pada Hepamax mengandung silimarin yang bersifat sebagai antioksidan sedangkan pada gula aren berdasarkan penelitian yang ada mengandung produk dari reaksi Mailard yaitu senyawa melanoidin yang bersifat sebagai antioksidan yang dapat meredam reaksi radikal bebas (Amin dkk., 2010).

Berbagai sistem yang dilakukan menyimpulkan bahwa melanoidin memiliki aktivitas sebagai penangkal radikal bebas dan sebagai pengkelat logam (Wang dkk., 2011).
Studi in vitro yang dilakukan terhadap isolat hepatosit dari tikus yang diinduksi dengan adriamycin untuk membentuk stres oksidatif menunjukkan bahwa pemberian melanoidin dengan kosentrasi $50 \mu \mathrm{g}$ dapat menghambat pelepasan LDH secara signifikan dan mengurangi kerusakan lipid yang disebabkan oleh peroksidasi lipid serta dapat menjaga pengurangan kadar glutation pada isolat hepatosit yang diinduksi adriamycin secara signifikan. Efek yang ditimbulkan oleh melanoidin tersebut diduga berkaitan dengan sifatnya sebagai antioksidan (Valls dkk., 2004).

Studi in vivo mengenai manfaat dari melanoidin juga sudah ada beberapa yang dilakukan diantaranya yaitu penelitian yang dilakukan terhadap senyawa melanoidin yang terdapat dalam kopi, dimana dalam penelitian tersebut diperoleh bahwa pemberian kopi yang mengandung sekitar 30\% senyawa melanoidin selama 10 hari dapat meningkatkan aktivitas glutation dalam hati tikus yang diinduksi stres 
oksidatif. Hal tersebut berhubungan dengan sifat dari melanoidin sebagai penangkal radikal bebas yang struktur kimianya memiliki cincin fenol (Esposito dkk., 2002).

\section{Hasil histopatologi Jaringan Hati Tikus}

Uji histopatologi yang dilakukn pada organ hati dilakukan untuk melihat keadaan organ ini setelah diinduksi dengan $\mathrm{CCl}_{4}$. Pada uji histopatologi ini yang dianalisis adalah keadaan inflamasi, perlemakan pada organ hati juga nekrosis. Hasil analisis pada uji histopatologi dapat dilihat pada tabel dibawah ini.

Hasil analisis dari organ hati berdasarkan pewarnaan dan pengamatan dibawah mikroskop dapat dilihat bahwa pada kontrol normal organ hati tidak mengalami perubahan apapun sedangkan pada kelompok kontrol negatif terjadi inflamasi atau peradangan di sekitar pembuluh darah yang ditandai dengan infiltrasi sel radang baik pada limfosit maupun neutrofil di sekitar pembuluh darah hati yang sangat besar. Selain terjadi inflamasi yang sangat besar pada kontrol negatif juga terjadi perlemakan yang ditandai dengan perubahan pada sitoplasma hati dengan vakuola lemak yang berbatas jelas dan nekrosis yang ditandai dengan perubahan pada inti dan sitoplasma pada beberapa lokasi di parenkim hati di sekitar vena sentralis hati yang sangat besar.

Tabel 4. Hasil analisis uji histopatologi organ hati

\begin{tabular}{llll}
\hline \multicolumn{1}{c}{ Kelompok } & Inflamasi & Perlemakan & \multicolumn{1}{c}{ Nekrosis } \\
\hline Normal & 0 & 0 & 0 \\
Kontrol negatif & +++ & +++ & +++ \\
Kontrol positif & ++ & 0 & 0 \\
Gula aren dosis $200 \mathrm{mg} / \mathrm{kg} \mathrm{BB}$ & ++ & +++ & ++ \\
Gula aren dosis $400 \mathrm{mg} / \mathrm{kg} \mathrm{BB}$ & ++ & 0 & 0 \\
\hline
\end{tabular}

Keterangan: tanda + menunjukkan adanya perubahan atau kerusakan. Semakin tinggi jumlah + menunjukkan tingkat perubahan atau kerusakan yang semakin besar.
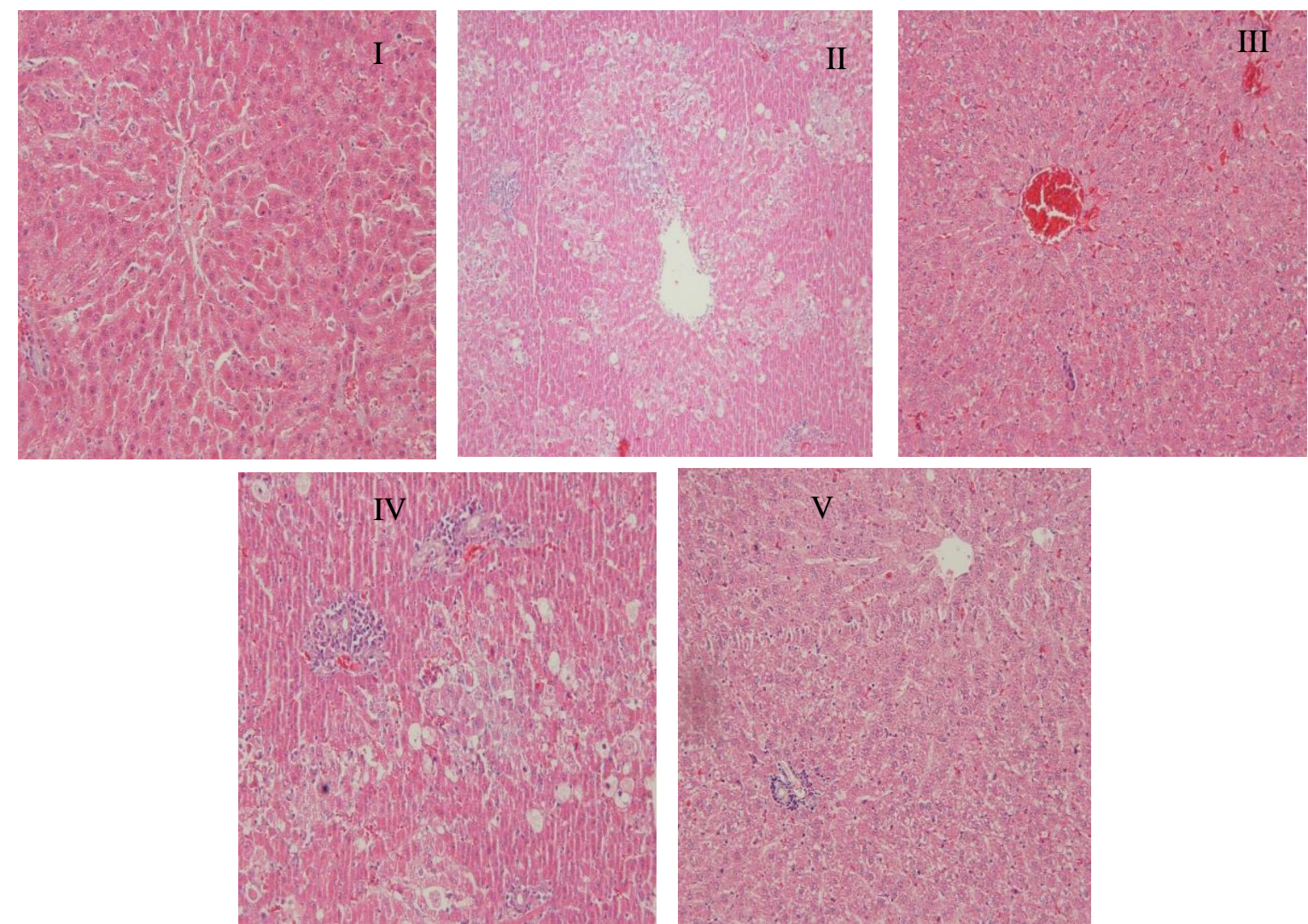

Gambar 1. Efek gula aren terhadap perubahan histologikal dalam hati tikus yang diperlakukan dengan $\mathrm{CCl}_{4}$. Keterangan: I (kelompok normal), II (kelompok kontrol negatif), III (kelompok kontrol positif, hepamax, IV (gula aren dosis $200 \mathrm{mg} / \mathrm{kg} \mathrm{BB}$ ), V (gula aren dosis $400 \mathrm{mg} / \mathrm{kg} \mathrm{BB}$ ). 
Hal ini sejalan dengan pemeriksaan atau identifikasi yang dilakukan terhadap serum darah tikus pada kelompok kontrol negatif dimana pada kelompok ini terjadi peningkatan kadar ALT, AST tertinggi yang mengidentifikasi bahwa telah terjadi kerusakan dan kelainan fungsi hati juga kadar kolesterol total yang tinggi.

Kelompok kontrol positif dan kelompok gula aren dosis $400 \mathrm{mg} / \mathrm{kg}$ BB menunjukkan keadaan hati yang sama. Dimana pada kedua kelompok ini juga terjadi inflamasi disekitar pembuluh darah namun tidak sebesar yang terjadi pada kontrol negatif. Pada kedua kelompok ini juga tidak menunjukkan terjadinya perlemakan dan nekrosis pada organ hati. Sedangkan pada kelompok gula aren dosis $200 \mathrm{mg} / \mathrm{kg}$ BB menunjukkan keadaan perlemakan pada hati yang sama dengan kontrol negatif namun inflamasi dan nekrosis yang terjadi pada kelompok dosisi gula aren $200 \mathrm{mg} / \mathrm{kg}$ BB lebih kecil dari pada kelompok negatif yang berarti pada dosis ini tetap memberikan perlindungan pada organ hati walaupun hanya sedikit.

\section{KESIMPULAN}

Berdasarkan hasil penelitian yang telah dilakukan diperoleh kesimpulan bahwa gula aren memiliki efek hepatoprotektif terhadap organ hati. Dosis gula aren $400 \mathrm{mg} / \mathrm{kg} \mathrm{BB}$ menunjukkan efek terbaik dan menyerupai kontrol positif dalam hal melindungi organ hati dari kerusakan yang ditimbulkan oleh $\mathrm{CCl}_{4}$.

\section{DAFTAR PUSTAKA}

Adriani, L., Rochana, A., Yulianti, A., Mushawwir, A. \& Indrayani, N. 2014. Profile serum glutamate oxaloacetate transaminase (SGOT) and glutamate pyruvate transaminase (SGPT) level of broiler that was given noni juice (Morinda citrifolia) and palm sugar (Arenga pinnata). Lucrari Stiintfice-Seria Zoothenie. 62, 101-105.
Amin, N.A.M., Mustapha, W.A.W., Maskat, M.Y. \& Ho, C.W. 2010. Antioxidative activities of palm sugar-like flavouring. The Open Food Science Journal. 4(1), 2329.

Choong, C.C., Anzian, A., Sapawi, C.W. \& Hussin, A.S.M. 2016. Characterization of sugar from Arenga pinnata and Saccharum officinarum Sugars. International Food Research Journal. 23(4), 1642-1652.

Esposito, F., Verde, V., \& Fogliano, V. Moderate coffee consumption increases plasma glutathione but not homocysteine in healthy subjects. Alimentary Pharmacology \& Therapeutics. 17(4), 595601.

Pelealu, K., Pontoh, J. \& Suryanto, E. 2011. Pengaruh pemanasan terhadap aktivitas antioksidan dalam pembuatan gula aren. Chemistry Progress. 4(2), 60-65.

Valls, V., Muniz, P. \& Franch, P.C. 2004. The Protective effects of melanoidins in adriamycin-induced oxidative stress in rat isolated hepatocytes. Journal of the Science of Food and Agriculture. 84(13), 17011707.

Wang, H.Y., Qian, H. \& Yao, W.R. 2011. Melanoidins produced by the Maillard reaction: Structure and biological activity. Food Chemistry. 128(3), 573-584. 